\title{
Всеволод Кузнецов
}

\section{ПРОСВЕЩЕНИЕ И ОНТОЛОГИЯ. РУССКОЕ ДОКЛАССИЧЕСКОЕ ПРОСВЕЩЕНИЕ: КИРЕЕВСКИЙ}

Данная работа продолжает цикл Просвещение и онтология. В предшествующей статье речь шла о заимствованном Просвещении, точнее - о приключениях европейского Просвещения в России. Теперь я буду исследовать Просвещение, освоенное и присвоенное, ставшее русским.

Я уже писал о том, что заимствованное Просвещение-в-России окончательно трансформируется в собственно русское Просвещение приблизительно в 30-х - 40-х гг. XIX в. [Кузнецов 2013: 123]. 20-е гг. ХIX в. - период подготовки этой трансформации. А восстание декабристов знаменует крах прежних просвещенческих форм.

Такой подход к определению времени возникновения данного феномена близок к точке зрения, которой придерживается ряд российских авторов. Так, Т. П. Баженова утверждает: «<..> “Век русского просвещения" не мог наступить ранее 40-х годов XIX века < .. > 40-60 годы в России - это канун 1789 года во Франции. Франция конца XVIII века и Россия второй половины XIX века перекликаются не только по социальноэкономическому положению, но и по характеру и движению общественной мысли» [Баженова 2004]. В другой работе, написанной ею же в соавторстве с В. С. Семиной, говорится, что идеи европейских просвещенцев отразились в общественном движении, представителями которого были «декабристы, революционеры-демократы, народники, соцдемократы» [Баженова... 2008]. Поскольку «декабризм в полной мере нельзя отнести к просветительскому типу мысли» [Баженова 2004], время существования русского Просвещения растягивается с 40-х гг. ХІХ в. примерно до конца этого столетия.

Данная концепция восходит к взглядам В. Ф. Пустарнакова [Пустарнаков 1999, 2001]. Последний рассматривал Просвещение как стадиальное явление, порождаемое ситуацией перехода «от добуржуазных отношений к буржуазным» [Пустарнаков 1999: 60]. По его мнению, «Просвещение - это специфическая, оригинальная, и в целом наиболее развитая, наиболее зрелая форма антифеодальной, антисредневековой, объективно буржуазной мысли» [ibid. 62]. Классической его моделью он считал французское Просвещение XVIII в. [ibid. 61].

Исследователь обозначил также начальную границу и время наибольшего подъема изучаемого явления: «“Век русского Просвещения” не мог наступить раньше 40х годов XIX в. Антифеодальные силы и ранние буржуазные идеи появились в Рос-

(C) В. Кузнецов, 2017 
сии много раньше, но “век русского Просвещения” мог наступить только тогда, когда в объективных условиях более или менее острого кризиса феодальнокрепостнического строя и под влиянием западноевропейских демократических и социалистических идей антифеодальные силы в России настолько осознали свою несовместимость со “старым режимом", что не могли больше ограничиваться критикой его, пусть важных, но отдельных сторон (как поступали прогрессивные мыслители - их предшественники), но встали на позиции отрицания его основ и могли уже более или менее осознать идеал нового строя, который должен был прийти на смену старому, дать своей антифеодальной программе теоретическое, в том числе философское обоснование. <..> Расцвет русского просветительства падает на 60-е годы XIX в. (Н. Г. Чернышевский, Н. А. Добролюбов, Д. И. Писарев и их единомышленники). Мировоззрения шестидесятников XIX в. - наиболее зрелые, классические формы Просвещения в России» [ibid. 76].

Главным недостатком всех этих концепций является рассмотрение Просвещения как стадиального явления и тесная привязка его к революционному движению. В то же время перспективным является изучение русского доклассического Просвещения в связи с процессом европеизации России. Т. П. Баженова анонсирует подобный подход, но не более того...

Меж тем ряд особенностей русского доклассического Просвещения связан именно с отношением просвещенцев к возможностям дальнейшей европеизации России. Мы видим здесь три базовых интенции: стремление продолжать процесс оевропеивания до победного конца, стремление трансформировать общество с опорой на модифицированные на русский манер европейские идеи и стремление к возвращению к собственным культурным основам, доходящее до полного отрицания европеизации.

В 30-х - 40-х гг. возникли три основные разновидности Просвещения - западническая, славянофильски-почвеническая и революционная. Каждая стремилась реализовать одну из базовых интенций, и все они достаточно жестко конкурировали между собой. Ситуация противостояния разных просвещенческих течений, судя по всему, не является чем-то специфически российским. Так, Йен Хантер обнаружил соперничающие течения в немецком Просвещении [Hunter 2003].

Тут, однако, необходимы уточнения. Речь не идет о совпадении ведущих направлений русского доклассического Просвещения с теми или иными течениями в русской философии (или шире - в культуре, в общественно-политической жизни). Вопрос о том, можно ли, скажем, всех представителей славянофильства как культурного течения числить по ведомству Просвещения, нуждается в специальном рассмотрении, однако а priori можно предположить, что ответ будет отрицательным. С другой стороны, среди представителей славянофильски-почвеннического Просвещения наверняка окажутся люди, не причисляемые обычно к движению славянофилов. То же относится и к западникам. И уж тем более далеко не все деятели революционного движения являются просвещенцами, равно как не все просвещенцы, о революции рассуждающие, готовы сами ее делать. Облик перечисленных направлений русского Просвещения определяется весьма широкими и общими культурными ориентациями - на вестернизацию страны, на поиск самобытных начал жизни и на революционное преобразование общества. Следует также отметить, что к просвещенцам можно причислить ряд мыслителей и вовсе стоящих вне главных направлений Просвещения.

Но какими бы разными ни были пристрастия просвещенцев, им всем приходилось так или иначе согласовывать свои онтологизационные и деонтологизационные устремления с действующими в культуре стратегиями онтологизации/деонтологиза- 
ции. Поэтому прежде чем начинать серьезный разговор о русском доклассическом Просвещении, следует остановиться на дальнейшей судьбе традиционных онтологизационых механизмов русской цивилизации. В период с начала XIX и до начала XX века уже знакомый нам онтологизационный инструментарий продолжает работать. Верховным Онтологизатором по-прежнему остается монарх, а онтологизация онтологизатора осуществляется в первую очередь через сакрализацию.

Правитель объявляется носителем особой святости: «<..> Эпитет святой может прилагаться ко всему, что относится к царю. Так, в 1801 г митр. Платон (Левшин) говорит о “святой крови” императрицы Марии Федоровны, текущей в жилах императора Александра <..> а в 1810-х годах управляющий Московской епархией архиепископ Августин (Виноградский) упоминает о “святой воле" и “святых молитвах" царя < .. >» [Живов... 1987].

Царь все еще может именоваться Христом. «<... Эта традиция не вовсе исчезает и во второй половине XIX в. Так, в “Слове в день коронования и священнейшего миропомазания Его Величества Благочестивейшего Государя Императора Александра Николаевича Самодержца Всероссийского”, произнесенном самарским соборным протоиереем Иоанном Халколивановым 26 августа 1871 г после неудавшегося покушения на царя, говорится: "В самые великие дни страстей Христовых, когда истинные христиане болезновали о своих грехах, новый сей Иуда злоумышлял на помазанника Божия, Христа Господня и во дни славного воскресения Христова, когда все радовались о воскресшем Спасителе, спешил поразить смертию бессмертного по славным деяниям Своим Царя нашего, надежду и радость нашу" <...> Таким образом, данная традиция распространяется на весь синодальный период» [ibid.].

Царь остается «земным Богом»: «<... К царю могут обращаться, как к Богу, и митрополит Платон (Левшин) даже специально обосновывает правомерность такого обращения» [ibid.]. Подобное смешение Бога и монарха имеет место и при отправлении церковной службы: «<...> наряду с молитвословными обращениями к монарху самые тексты подлинного церковного молитвословия могут сливаться с панегириком монарху. На это обстоятельство специально обращает внимание Н И. Ильминский в своем письме К. П. Победоносцеву от 17 марта 1884 г.» [ibid.].

После реформы Петра царь становится главою церкви. «<...> Синод берет на себя функции собора, а император выступает в роли патриарха. Императорскими же указаниями могут регулироваться и любые другие стороны церковной жизни (вплоть до разрешения на пострижение в монашество <...>)» [ibid.]. При этом царь, по крайней мере частично, перенимает на себя и харизму патриарха [там же]. «Убеждение в харизматической основе функций монарха как главы церкви может проявиться в том, что монарх воспринимается как священнослужитель. <..> Это восприятие царя как священника приводило к парадоксальному переосмыслению византийской теории симфонии между “священством" и “царством". Так, на Поместном Соборе 1917/18 г. прозвучала мысль, что “"царство" и "священство" до сих пор в России были объединены в царской власти" <..> И в самом деле, объединение функций главы, государства и главы церкви представлялось естественным, что, когда в 1905 г. возник вопрос о восстановлении патриаршества, Николай II немедленно предложил себя в патриархи <...>» [ibid.].

Священным становится весь клан Романовых: «<...> Сакрализация распространяется на всю царскую семью, высокоторжественные дни с их пышностью и награждениями складываются в особую систему религиозного почитания царя и царского дома. <..> Распространение сакральности монарха на царствующий дом 
отражается как в духовном красноречии, так и в одической поэзии. Так, митрополит Платон в <..> речи на прибытие Александра I в Москву (1801 г.) говорит, имея в виду царствующий дом, о “всей священной крови” императора < ...>» [ibid.].

Подводя итоги своим разысканиям, В. М. Живов и Б. А. Успенский констатируют всеохватность освящения правителя: «Таким образом, сакрализация монарха становится фактом церковной жизни и религиозного быта русского народа. Сакрализация захватывает самые разнообразные сферы - государственное управление, национальное историческое самосознание, богослужение, церковное учительство (проповедь, преподавание Закона Божиего и т. п.) и, наконец, самую духовность. Более того, царское самодержавие начинает приобретать статус вероисповедного догмата. Почитание царя становится рядом с почитанием святых, и, таким образом, культ царя делается как бы необходимым условием религиозности» [ibid.]. Далее следует ссылка на весьма любопытный опус, вышедший в 1906 г.: «Красноречивое свидетельство этого находим в монархической брошюре "Власть самодержавная <...>, где подчеркивается именно догматический статус царского культа: "Истина самодержавия царей православных, то есть поставление и утверждение их на престолах царств от Самого Бога, так священна, что по духу учения и законоположений церковных, она возводится некоторым образом на степень догмата веры, нарушение и отрицание которого сопровождается отлучением от церкви" <...>» [ibid.].

В начале XX века острый цивилизационный кризис привел к актуализации наиболее архаичных мифологем, связанных с культом правителя. О. М. Морозова высказала весьма продуктивную идею о том, «что важную роль в крушении российской монархии сыграл древний архетип “священного, или сакрального царя”, предполагающий ответственность правителя жизнью за благополучие страны» [Морозова 2006]. Уточняя эту мысль, можно охарактеризовать ситуацию, сложившуюся накануне революции примерно так. Произошло расщепление комплекса представлений о священном правителе. Его византинизированные и христианизированные составляющие вступили в противоречие с языческими. В результате отлаженный онтологизационный механизм разбалансировался и стал работать на деонтологизацию, что весьма поспособствовало крушению монархии.

Для Романовых было характерно отождествление себя с государством и представление о России как о своей вотчине [Морозова 2010: 162-164]. Подобные взгляды вообще архетипичны для русской культуры и восходят еще к допетровским временам [Лукин 2000: 20-21, 28]. Здесь нам открывается один из механизмов, при помощи которого правитель осуществлял свои онтологизационные функции. Речь опять-таки идет об онтологизации через сакрализацию: принадлежащее священной особе делается священным и возрастает в бытии. Этот механизм действует вплоть до падения монархии.

Итак, Просвещению по-прежнему приходилось иметь дело с традиционными для России онтологизационными механизмами. Но само оно не стояло на месте, постоянно развивалось и разрасталось.

И поскольку русское доклассическое Просвещение в целом весьма богато и разнообразно, выбрать репрезентативный материал для выявления каких-то общих закономерностей не так просто. Поэтому я пойду вполне традиционным путем: рассмотрю идеи отцов-основателей трех главных разновидностей Просвещения - Чаадаева, И. В. Киреевского и Герцена.

Но здесь возникает вопрос: можно ли считать этих троих деятелями Просвещения? Я попытаюсь показать это, используя схему, опробованную при анализе конфуцианства [Кузнецов 2014]. 
Сейчас речь пойдет о Киреевском. Прежде всего следует отметить, что к этому мыслителю вполне применимы сделанные выше оговорки. Философа, конечно, причисляют к движению славянофилов [Каменский 2003; Антонов 2006: 6; Василий... 2006: 45-47]. Но в то же время «трудно < ..> представить И. В. Киреевского ведущим идеологом складывающегося направления», ведь сам он пытается от него дистанцироваться [Каплин 2008: 120; Каплин 2011: 129-130; Платонов 2009: 283]. И вообще «имеются основания думать, что во всяком случае при жизни Киреевского ни философ “славян”, ни философа “славяне” в полной мере за культурно-философских единомышленников не считали» [Судаков 2011: 161; ср. Судаков 2012: 5-6]. Зато когда речь идет о славянофильствующем Просвещении, его творчество вполне может служить начальной точкой отсчета. Впрочем, не буду забегать вперед...

Для начала можно констатировать наличие точек соприкосновения взглядов Киреевского с мировоззренческим полем европейского Просвещения. В. А. Котельников отмечает, что в начале своей деятельности мыслитель увлекался идеями французских просвещенцев [Котельников 1984: 10-11]. По мнению исследователя, в 1820 - 30-х гг. мировоззрение философа было близким к идеям классического европейского Просвещения [ibid. 10]. Наконец, в 1827 г. Киреевский писал А. И. Кошелеву: «Я могу быть литератором, а содействовать к просвещению народа не есть ли величайшее благодеяние, которое можно ему сделать?» [Киреевский 1984: 288]. В свете симпатий философа к Гельвецию [ibid.] подобное заявление можно расценивать как демонстрацию стремления не просто к просветительской, но именно к просвещенческой деятельности.

Уместным, однако, будет предположение, что после своего обращения философ должен был перейти от просвещенчества к религиозной пайдейе. Кроме того, К. М. Антонов считает Киреевского причастным к некоему глобальному перевороту, о котором пишет как «о некоем решающем событии в духовной истории человечества, об историческом проекте, не менее фундаментальном, чем проект Просвещения, но направленном в противоположную сторону: о проекте религиозного возрождения, осуществлявшемся с помощью философии» [Антонов 2006: 6]. Но так ли это?

$\mathrm{O}$ «глобальном проекте религиозного возрождения» мы поговорим чуть позже. А вот вопрос о возможном переходе Киреевского к религиозной пайдейе следует прояснить прямо сейчас.

Рассмотрим один из подготовительных фрагментов философского сочинения, которое так и не было написано Киреевским. Здесь автором провозглашается необходимость решения вполне эдукационистской задачи: «развитием законов самобытного мышления подчинить весь смысл западной образованности господству православно-христианского убеждения» [Киреевский 1911: I, 270]. Философ говорит также о противоречии западной образованности, западного просвещения самому духу просвещения христианского [ibid.]. Однако он полагает возможным «примирение обеих образованностей в таком мышлении, которого основание заключало бы в себе самый корень древнерусской образованности, а развитие состояло бы в сознании всей образованности западной и в подчинении ее выводов господствующему духу православно-христианского любомудрия» [ibid. 265].

Чтобы понять, о чем, собственно, идет речь, следует обратить внимание на смысл, вкладываемый мыслителем в понятия просвещение и образованность, которые фактически являются для него синонимами. Как отмечают исследователи творчества философа, «термины "просвещение" и “образование” < .. > приобрели у Киреевского то значение, которое несколько позже Ап. Григорьев, Н. Н. Страхов и Н. 
Я. Данилевский стали вкладывать в понятие “культура” (или “цивилизация”)» [Ильин 2008: 273 (прим. 1); ср. Маслин 2007: 246; Котельников 1984: 12; Зеньковский 1991: I.1, 11]. Подобный подход является логическим итогом представлений, согласно которым общественный прогресс зависит от прогресса просвещения. Теперь цивилизация как результат прогресса оказывается тождественна просвещению, достигшему в этом результате некой полноты.

В то же время просвещение понимается как процесс преобразования действительности под воздействием эдукации и как плод этого процесса - некое состояние духовности. В свое время 3. А. Каменский утверждал, что историософия Киреевского «должна быть названа религиозно-идеалистической концепцией культурно-исторических типов» [Каменский 2003]. Он же указал на просвещение-образованность (во втором смысле) как на основу культурно-исторического типа [ibid.].

Действительно, по мнению Киреевского, «неразрывная связь существует между развитием образованности и первыми элементами, из которых слагается народная жизнь» [Киреевский 1984: 146]. Таким образом, можно говорить о том, что православная образованность формирует основы русской цивилизации и саму природу русского народа. Процесс их создания описан следующим образом: «Учения св. отцов православной церкви перешли в Россию <.. > Под их руководством сложился и воспитался коренной русский ум, лежащий в основе русского быта»; «Таким образом, русское общество выросло самобытно и естественно, под влиянием одного внутреннего убеждения, церковью и бытовым преданием воспитанного» [ibid. 222, 226]. Между православной образованностью и бытом существует тесная связь. Сохранение одного обуславливает и сохранность другой, поскольку изначальное просвещение как бы законсервировано в основах быта и ментальности народа: «<..> Этот русский быт, созданный по понятиям прежней образованности и проникнутый ими, еще уцелел почти неизменно в низших класcах народа < .. >» [ibid. 223]; «<..> Первобытное просвещение России хранится, не развиваясь, в нравах, обычаях и внутреннем складе ума так называемого простого народа < .. >» [Киреевский 1911: I, 267].

Изначальное просвещение онтологизировано, и само способно онтологизировать. Киреевский указывает на некоторые онтологические характеристики, сообщенные им русской природе: «Древнерусская православно-христианская образованность, лежавшая в основании всего общественного и частного быта России, заложившая особенный склад русского ума, стремящегося ко внутренней цельности мышления, и создавшая особенный характер коренных русских нравов, проникнутых постоянною памятью об отношении всего временного к вечному и человеческого к Божественному <...>» [ibid. 265].

Таким образом, мы сталкиваемся тут с панэдукационистской установкой, в которой эдукация и ее плоды составляют единое целое, а потому изменение стратегии эдукационной деятельности означает изменения на цивилизационном уровне (поэтому не слишком убедительными выглядят попытки А. К. Судакова произвольно разделять в построениях Киреевского характер просвещения, само просвещение и образованность [Судаков 2012: 216]).

Создание нового типа образованности предполагает работу с самим естеством народа и глубинными основаниями цивилизации - задача достаточно глобальная, чтобы считаться просвещенческой. Выше уже было указано, что Киреевский в принципе допускает формирование природы народа посредством эдукационного воздействия. Что же касается нового мышления, которое он предполагает воспитать, 
то здесь не обойтись, во-первых, без восстановления поврежденной природы русских, а во-вторых, без ее коренной переделки.

Последнее как будто бы не очевидно. В работе «Обозрение современного состояния литературы» Киреевский отрицает возможность пересоздания русского человека путем усвоения западной образованности [Киреевский 1984: 152]. Более того, мыслитель полагает, что осуществление такого пересоздания привело бы к уничтожению народа [ibid.]. «Ибо что такое народ, если не совокупность убеждений, более или менее развитых в его нравах, в его обычаях, в его языке, в его понятиях сердечных и умственных, в его религиозных, общественных и личных отношениях, - одним словом, во всей полноте его жизни?» [ibid. 153]. Пересоздание невозможно и чисто технически, поскольку «в конечном развитии просвещения европейского нет начала господствующего. Одно противоречит другому, взаимно уничтожаясь» [ibid.]. И вообще у западного и русского обществ - разные базовые начала. Первое стоит на мнениях, второе - на убеждениях. «Мнение, убеждение - две совершенно особые пружины двух совершенно различных общественных устройств. <..> Убеждение есть невыисканное сознание всей совокупности общественных отношений; мнение есть преувеличенное сочувствие только той стороне общественных интересов, которая совпадает с интересами одной партии и потому прикрывает ее своекорыстную исключительность обманчивым призраком общей пользы» [ibid. 227].

Однако по той же логике синтез западной и русской образованности не может оставить естество народа неизменным. Киреевский должен был это понимать и, скорее всего, понимал и подразумевал. Поэтому, наверное, и показалось Н. П. Ильину, что сквозь рассуждения о православии и православности просвечивает у мыслителя убеждение в возможности работать с народом, как с неживой материей, вылепливая из нее нам угодное [Ильин 2008: 311].

Теперь - о путях решения поставленной философом задачи. Развитие самобытного православного мышления «должно быть общим делом всех людей верующих и мыслящих, знакомых с писаниями св. отцов и с западною образованностию» [Киреевский 1911: I 270]. Подвиги какого-либо культурного героя-гения здесь не только не нужны, но скорее вредны, поскольку «гениальность, предполагающая непременно оригинальность, могла бы даже повредить полноте истины» [ibid.]. На выходе Киреевский хочет получить новую философию («новую науку мышления», «высшее философское начало») [там же]. Основа и зерно такой философии - «живое и чистое любомудрие св. отцов» [ibid.]. «Но любомудрие св. отцов представляет только зародыш этой будущей философии, которая требуется всей совокупностию современной русской образованности, - зародыш живой и ясный, но нуждающийся еще в развитии и не составляющий еще самой науки философии. Ибо философия не есть основное убеждение, но мысленное развитие того отношения, которое существует между этим основным убеждением и современною образованностию. Только из такого развития своего получает она силу сообщать свое направление всем другим наукам, будучи вместе их первым основанием и последним результатом. Думать же, что у нас уже есть философия готовая, заключающаяся в св. отцах, было крайне ошибочно. Философия наша должна еще создаться, и создаться, как я сказал, не одним человеком, но вырастать на виду, сочувственным содействием общего единомыслия» [ibid. 270-271].

Киреевский говорит о вещах вполне практических - о создании новой философии. Но тут же он пытается превратить этот проект в утопию, замышляя нечто, вроде федоровского «общего дела» (у него и терминология та же), только меньших масштабов. Федорову для его науки требуется участие всего народа, а Киреевский согласен огра- 
ничиться широкими массами образованного населения. Становление чаемой философии мыслится как естественный процесс развития культуры, поэтому оригинальность, гениальность и «всякие остроумные открытия» здесь совершенно неуместны.

И тут становится ясной невозможность числить Киреевского по ведомству религиозной пайдейи. Проблема в том, что его проект при всем флере религиозности требует исключительно человеческих усилий. Иное дело - религиозная пайдейя.

Обратимся к посланиям апостола Павла. Он признает необходимость человеческого усилия в деле спасения и обращается к членам римской церкви с призывом: «...В усердии не ослабевайте; духом пламенейте; Господу служите...» (Рим. 12: 11). Он видит общину верных как содружество людей, способных наставлять и воспитывать друг друга: «...Вы полны благости, исполнены всякого познания и можете наставлять друг друга...» (Рим. 15: 14). Но для осуществления проекта, с которым пришел Павел, не нужно создавать новых философий: «...Возвещаем не от человеческой мудрости изученными словами, но изученными от Духа Святаго, соображая духовное с духовным» (1Кор. 2: 13). Почему? «Ибо мы соработники у Бога...» (1 Кор. 3: 9). Именно Бог является здесь главным деятелем, хоть и действует через людей: «...Бог производит в вас и хотение и действие по Своему благоволению» (Флп. 2: 13). Иными словами, в системе христианской пайдейи все определяет Бог, а просвещенец, даже когда берется рассуждать о Нем, все равно ищет, как бы поставить на Его место человека.

Но вернусь к утопизму и практичности. Более практичными выглядят педагогические рекомендации Киреевского, сформулированные в работах «Записка о направлении и методах первоначального образования народа в России» и «О нужде преподавания церковнославянского языка в уездных училищах» [Киреевский 2007: 121-148]. Однако стремление добиться, чтобы для учащихся «при окончании <...> ученья раскрылась дверь в высшее училище - Церковь» [ibid. 145], для того времени тоже было утопическим.

Таким образом, некая практическая струя в мысли нашего философа определенно присутствует, но теряется в море утопизма. Что же касается выдвижения на первый план слишком человеческого, то с этим у мыслителя определенно все в порядке.

Новая философия «должна уничтожить болезненное противоречие между умом и верою, между внутренними убеждениями и внешнею жизнию» [ibid. 270]. Речь идет об утверждении утопии цельного человека: о возвышении разума, стремящегося «собрать в одну неделимую цельность все свои отдельные силы, которые в обыкновенном положении человека находятся в состоянии разрозненности и противоречия <...> [Киреевский 1984: 260]. Н. П. Ильин доказывает, что данная утопия возникла под влиянием немецких романтиков и не имеет отношения к православию (хотя Киреевский и пытался ее выдать за квинтэссенцию всего православного) [Ильин 2008: 304-307].

Существуют и иные подходы к проблеме. В. Н. Катасонов полагает, что «точка зрения авторов концепции целостного разума генетически и логически была укоренена в христианском мировоззрении, в православной основе русской культуры» [Катасонов 2000]. Исследователь связывает данные представления о целостности с исихазмом и утверждает, будто Киреевский «проникался духом идущей через века православной традиции “умного делания”» в общении со старцами Оптиной пустыни [ibid.]. А Д. Е. Муза рассматривает «целостного человека» как антропологическое задание восточно-христианского культурного проекта. Это задание пыталась выполнить Московская Русь, но петровская модернизация положила таким попыткам конец [Муза 2009: 87-88]. «"Остатки" этого проективного задания» как раз и «были переосмыслены и реинтерпретированы в условиях последовательной диффузии западных форм жизни 
и ценностей» Киреевским [ibid. 88]. Последний опирался в своих реконструкциях на исихастскую антропологию [ibid. 89]. И наконец, С. Гальперин связывает концепцию цельного знания у Киреевского с учением Исаака Сирина [Гальперин 2010].

Я, однако, считаю, что ближе к истине все же Н. П. Ильин. Даже если полностью отбросить возможность немецкого влияния и принять версию о преимущественном воздействии на Киреевского исихазма, придется признать: философ коренным образом изменил суть православного учения и превратил его в светскую утопию. В самом деле, В. Н. Катасонов пишет об исихастах: «Исцеленный благодатию разум подвижника видит Духом Святым Самого Бога, Божественные энергии, - видит особый Свет, тождественный тому, который был показан апостолам при Преображении Иисуса Христа на горе Фавор» [Катасонов 2000]. Здесь перед нами в первую очередь действие Самого Бога, Его благодати, а также соработничество человека с Ним.

А у Киреевского? Философ утверждает, будто «равновесие внутренней жизни» достигается не действием благодати, стяжаемой на высших ступенях духовного делания, но присуще каждому человеку, воспитанному «в обычных преданиях православного мира» [Киреевский 1984: 222]. В итоге эта цельность превращается попросту в свойство русской этнической природы. Поэтому «русский человек каждое важное и неважное дело свое всегда связывал непосредственно с высшим понятием ума и с глубочайшим средоточием сердца» [ibid. 230]. Сформированы эти свойства этнической природы широкомасштабным эдукационным усилием церкви, а восстановлены могут быть эдукационным усилием просвещенцев.

Эта метаморфоза цельности часто остается вне поля зрения исследователей творчества Киреевского. Вот характерный пример. Иеромонах Василий (Саяпин) и А. М. Шарипов попытались проверить рассуждения философа на предмет соответствия их святоотеческим учениям, но разобраться в нюансах во многих случаях не потрудились. Так, воспроизведя пассаж о присущей русскому человеку цельности, авторы сопоставляют его с фрагментом из «Поучений аввы Дорофея», где речь идет о подвижнике, практикующем непрестанную молитву [Василий... 234-236]. Вообще авва Дорофей составлял поучения для своих учеников, т. е. монахов [Авва Дорофей 2010: 11-12]. Киреевский же ведет речь о «последнем крестьянине» [Киреевский 1984: 230], который в реальной истории и вовсе был полуязычником. И странно ожидать от этого крестьянина следования подвижническим практикам.

Тут стоит прислушаться к замечаниям А. К. Судакова, по мнению которого цельность бытия у Киреевского «не сводится к одной лишь непротиворечивой связности аскетически-религиозной практики» [Судаков 2012: 23]. Исследователь настойчиво подчеркивает, что «Киреевский распространяет свою общефилософскую идею цельности бытия за пределы собственно монашески-аскетической цельности духа» [ibid. 29]. Иными словами, христианские подвижники и наш философ говорят о разной цельности.

Здесь уместно вернуться к проблеме участия Киреевского в некоем глобальном проекте религиозного возрождения, противостоящем Просвещению. К. Антонов рассуждает «о вариантах такого проекта в виде французской (де Местр), немецкой (Шеллинг, Баадер, Якоби), несколько позже - итальянской (Джоберти, Розмини), индийской, еврейской (Коген, Бубер, Розенцвайг) и т. д. религиозной философии» [Антонов 2006: 6]. Сомневаюсь, что названные феномены вообще можно свести к какому-то единству. Впрочем, понять, есть ли у них некое объединяющее начало, можно, лишь проделав специальное исследование. Однако в ряде случаев речь определенно идет не о возрождении религии через философию, а о подмене религии фи- 
лософией. И называть подобную манипуляцию антипросвещенческой не стоит, поскольку сами просвещенцы ее постоянно осуществляли.

Что же касается проекта, созданного Киреевским, то его стремление создать новую - светскую, но окрашенную в религиозные цвета - философию, оттолкнувшись от святоотеческой мысли, прокладывает путь к осуществлению той же манипуляции.

Но это еще не все. Иеромонах Василий и А. М. Шарипов пишут: «<.. > Некоторое расхождение во взглядах И.В. Киреевского со святыми отцами заключается не в исторических оценках, а в излишне оптимистическим взгляде Ивана Васильевича на дальнейшее развитие России и Европы, в соединении лучших черт образованности которых он и видит отправную точку для начала новой эпохи в образовательном и философском развитии Европы» [Василий... 257]. Если не пытаться смягчить несмягчаемое, нужно констатировать, согласно святоотеческой мысли, проект Киреевского неосуществим. Однако сравнение высказываний Феофана Затворника и нашего мыслителя, проделанное названными авторами [ibid. 252-253], позволяет увидеть более серьезные расхождения. Киреевский говорит о синтезе русской и западноевропейской образованности. Феофан Затворник - об отказе от последней. Причем предполагает, что точка невозвращения уже пройдена, а потому избавиться от «западной тьмы» не удастся. Как видим, с точки зрения ортодоксального православия, и проект негоден, и добрых результатов от него ждать не приходится.

Словом, с ортодоксальным православием проект Киреевского согласуется плохо. Но в России XVIII в. существовала и иная традиция, которую именуют православным или религиозным Просвещением [Цапина 2004; Земницкая 2011; Михайлов 2013; Чикова 2015; Wirtschafter 2009, 2010]. Она была порождена «синтезом русского православия и западных идеологий Нового времени» [Михайлов 2013: 107]. Деятелями, формировавшими данную традицию, выступали клирики. Так, Э. К. Виртшафтер обращает внимание на учение митрополита Платона (Левшина) [Wirtschafter 2013]. Но пришла новая эпоха, и проект Киреевского продолжил ту же традицию, теперь уже на светской основе. Продолжил, видоизменяя и утопизируя некоторые православные конструкты.

На этом пути идея цельного духа постепенно подчиняет себе все творчество Киреевского. Однако при столкновении утопии с реальностью мыслитель начинает чувствовать ее коренной порок и ощущает: если вожделенная цельность и может осуществиться в человеке, то лишь под действием благодати Божией, а не по человеческому хотению. И Киреевский молится о даровании ему такой цельности [Киреевский 2002: 428].

И, наконец, вербализм. Киреевский подчеркивает неразрывную и сущностную связь русской образованности и литературы: «<..> В других государствах литература есть одно из второстепенных выражений образованности, у нас она главнейшее, если не единственное» [Киреевский 1984: 81]. Связь эта зиждется на роли слова как формы и выражения человеческого духа: «Слово, как прозрачное тело духа, должно соответствовать всем его движениям» [ibid. 281]. Не стоит сбрасывать со счетов и представления о сакральности слова, присущие многим русским мыслителям. Так, брат философа П. В. Киреевский фактически отождествляет слово человеческое, слово литературное со Словом как ипостасью Пресвятой Троицы: «Я давно уверен был, что важнейшей дорогою к цели для русского должно быть слово, которому впоследствии предназначено воплотиться и быть искупителем» [цит. по Киреевский 1984: 345 (прим. 1)]. Вряд ли И. В. Киреевский прошел мимо этих представлений. Следует также указать на излюбленную философом идею об особой роли церковно-славянского языка [Рожковский 2004], к которой я еще вернусь. 
Итак, учение Киреевского соответствует основным параметрам Просвещения.

А теперь перейду непосредственно к рассмотрению онтологических аспектов мировоззрения Киреевского. И начну с его концепции просвещения-цивилизации.

Развитие просвещения-цивилизации, по мнению философа, есть процесс всемирно-исторический. При этом каждая отдельная культура предстает как синтез общечеловеческого и национального: «<..> Государства, причастные образованности европейской, внутри самих себя совместили все элементы просвещения всемирного, сопроникнутого с самою национальностью их» [Киреевский 1984: 76]. При этом «просвещение в истинном смысле сего слова» есть «не отдельное развитие нашей особенности, но участие в общей жизни просвещенного мира» [ibid.]. Это убеждение проходит через все творчество Киреевского [Устрялов 1916].

Совмещаются общечеловечность с национальностью следующим образом: «Каждая эпоха человеческого бытия имеет своих представителей в тех народах, где образованность процветает полнее других. Но эти народы до тех пор служат представителями своей эпохи, покуда ее господствующий характер совпадается с господствующим характером их просвещения. Когда же просвещение человечества, довершив известный период своего развития, идет далее и, следовательно, изменяет характер свой, тогда и народы, выражавшие сей характер своею образованностью, перестают быть представителями всемирной истории. Их место заступают другие, коих особенность всего более согласуется с наступающею эпохою. Эти новые представители человечества продолжают начатое их предшественниками, наследуют все плоды их образованности и извлекают из них семена нового развития» [Киреевский 1984: 77].

Перед нами первая онтологическая схема, построенная Киреевским. Объектом онтологизации и эдукации (онтологизации через эдукацию) тут предстает человечество. Но человечество не есть нечто всегда себе равное. Оно изменчиво и в движении своем проходит разные стадии-эпохи, каждая из которых являет собой определенный этап всечеловеческого возрастания в бытии. Это развитие человечества есть развитие просвещения. Именно образованность как процесс выступает здесь в качестве онтологизирующего фактора. Характер же той или иной эпохи есть характер ее просвещения. В данном случае последнее следует понимать как определенное духовное состояние. Выразителем характера эпохи становится тот или иной народ, но для этого особенности его просвещения (опять-таки духовного состояния) должны соответствовать особенностям просвещения эпохи. Поэтому «просвещение каждого народа измеряется < .. > единственно участием его в просвещении всего человечества, тем местом, которое он занимает в общем ходе человеческого развития» [ibid. 77-78].

Просвещение определяется также как умственная жизнь человеческого рода, всемирная прогрессия ума, мысль, наука [ibid. 76, 77]. Подобные дефиниции позволяют нам определить, так сказать, первичный носитель бытия. В этой роли всегда выступает некая идея, мысль [там же, с. 76]. Таким образом, идея как носитель кванта бытия выступает в роли движителя, инициирующего развитие просвещенияобразованности. Движение просвещения есть процесс возрастания бытия. Просвещение как состояние характеризует степень онтологического роста.

Но так бывает лишь в правильном просвещении (просвещении в истинном смысле слова), каким для раннего Киреевского было просвещение европейское. В неправильном (российском) просвещении «место мысли заступает лицио, частное событие, самозванецу» [ibid.]. Замена оборачивается онтологической неподлинностью, поскольку самозванец всегда обладает лишь видимостью бытия. Частное событие (со-бытие) можно в данном контексте трактовать как неподлинное совместное бытие причастных 
к нему лиц. В результате просвещение не приобщает к всеобщности, а вырождается в развитие особенности народа-цивилизации.

Когда же речь заходит об отдельном народе, появляется вторая онтологическая схема. Пытаясь охарактеризовать онтологическую основу единичного просвещенияцивилизации, Киреевский пользуется понятиями действительность, Жизнь, действительность жизни [ibid. 44, 66-68]. Н. П. Ильин расценивает подобное понимание просвещения как «утилитарно-позитивистское» [Ильин 2008: 272-273]. Я, однако, полагаю, что исследователь ошибается.

Присмотримся к жизни и действительности внимательнее. Еще в «Обозрении русской словесности 1829 года» мыслитель писал: «Нам необходима философия: все развитие нашего ума требует ее. <..> Нама философия должна развиться из нашей жизни, создаться из текущих вопросов, из господствующих интересов нашего народного и частного быта» [Киреевский 1984: 51-52]. Тот же Н. П. Ильин отметил, что «слово “быт”, которое часто встречается у Киреевского и Хомякова, повидимому, соединяло для них абстрактное понятие бытия с ощущением конкретной жизни» [Ильин 2008: 303 (прим. 1)]. Но в приведенной цитате жизнь и быт едва ли не синонимы. Логично предположить, что, говоря о жизни, действительности и быте, Киреевский ищет бытия, понятого как здесь-и-теперь бытие.

Быт и жизнь увязаны также с понятием народность. Киреевского в первую очередь интересуют народный быт и народная жизнь (хотя не только). Жизнь-бытие, быт-бытие народа должны быть основой и истоком истинного просвещения.

Однако жизнь-быт не последняя основа просвещения-цивилизации. «<..> По основному взгляду Киреевского, сама-то жизнь народов и их регионов, равно как и их духовная деятельность, имеют своим основанием некие "начала", в числе которых главнейшими являются религия и образ мышления» [Каменский 2003].

Как уже говорилось выше, в основе всего лежит религиозная образованность [Киреевский 1984: 222-223]. Она составляет внутреннюю основу бытия народа и отдельного человека [ibid. 159]. Суть ее раскрыта Киреевским в концепции внутренней и внешней сторон просвещения. Об этих двух сторонах сказано следующее: «Одна образованность есть внутреннее устроение духа силою извещающейся в нем истины; другая - формальное развитие разума и внешних познаний» [ibid. 158]. Итак, внутреннее просвещение определяется высшей истиной. Эта истина и соответствующее ей духовное состояние могут непосредственно исходить «от того начала, которому покоряется человек» [ibid.], т. е. от Бога. Для внутренней образованности «нет изменяющегося развития, есть только прямое признание, сохранение и распространение в подчиненных сферах человеческого духа <...> [ibid.]. Внешняя осуществляется в процессе человеческой деятельности. Она вся развитие и движение. Внутренняя образованность работает как онтологизационный механизм. Она «имеет существенное значение для жизни, влагая в нее тот или другой смысл, ибо из ее источника истекают коренные убеждения человека и народов; она определяет порядок их внутреннего и направление внешнего бытия, характер их частных, семейных и общественных отношений, является начальною пружиною их мышления, господствующим звуком их душевных движений, краскою языка, причиною сознательных предпочтений и бессознательных пристрастий, основою нравов и обычаев, смыслом их истории» [ibid.]. При правильном соотношении сторон внутренняя определяет движение внешней: «Покоряясь направлению этой высшей образованности и дополняя ее своим содержанием, вторая образованность устрояет развитие наружной стороны мысли и внешних улучшений жизни < .. >» [ibid.]. 
Религиозная образованность формирует ментальность народа [ibid. 222]. Последняя составляет фундамент всего просвещения как цивилизации и как высшего духовного состояния, а также перводвигатель просвещения как процесса: «Как язык народа представляет отпечаток его природной логики и если не выражает его образа мыслей вполне, то по крайней мере представляет в себе то основание, из которого беспрестанно и естественно исходит его умственная жизнь, так и разорванные, неразвитые понятия народа еще не мыслящего образуют тот корень, из которого вырастает высшая образованность нации. Оттого все отрасли просвещения, находясь в живом сопроницании, составляют одно неразрывно сочлененное целое» [ibid. 147]. Ментальность в свою очередь формирует жизнь-быт [ibid. 222], а уже из жизни-быта под воздействием эдукационной деятельности церкви вырастает убеждение, формирующее общество [ibid. 226]. Говоря о становлении русского общества, Киреевский также указывает, что жизнь-быт-обычай создает целостного человека и целостную семью как основную социальную ячейку [ibid. 230-231].

Рассмотренные схемы составляют онтологизационную модель, которую можно назвать этноцивилизационной. Здесь Киреевский пытается представить просвещение-цивилизацию как самоонтологизирующийся феномен. Внешний источник бытия - Бог - присутствует где-то на периферии, и роль его намеренно затушевана. Данная модель предполагает предельную онтологизацию эдукационной деятельности, причем не только в глобальном масштабе.

В «Записке о направлении и мето́дах первоначального образования народа в России» Киреевский приходит к выводу, «что направление народного образования должно стремиться к развитию чувства веры и нравственности преимущественно перед знанием» и «что лучшее средство к сей цели есть изучение словенского языка, дающее возможность иерковному богослужению действовать прямо на развитие и укрепление народных понятий» [Киреевский 2007: 139].

А в рассуждении «О нужде преподавания церковнославянского языка в уездных училищах» мыслитель добавляет: «Все познания человеческие, в совокупности своей, составляют один общий организм, одно, так сказать, тело ума человеческого. Господственная часть этого тела, голова этого организма, заключается, без сомнения, в религиозных и нравственных убеждениях. <...> Ибо вся сущность религиозного знания заключается не в догматике, не в символе, а в живом сочувствии с духовною жизнью Церкви. Потому, чтобы уездные училища вполне достигали своей цели, полезно бы было, кажется, особенно в некоторых местностях, чтобы в устройство их взошло более церковного элемента, и именно столько, сколько нужно для того, чтобы ученики могли без труда читать церковные книги и понимали бы хотя несколько конструкцию славянской речи» [ibid. 146-147].

В.Б. Рожковский указывает на особый онтологический статус, придаваемый церковнославянскому языку мыслителем. Последний выступает как форма выражения сакрального «внутреннего слова» [Рожковский 2004]. Поэтому введение этого языка в учебный процесс становится способом реонтологизации человека посредством эдукации.

Этноцивилизационная онтологическая модель была новшеством, предложенным русским Просвещением. А как относился Киреевский к традиционным механизмам онтологизации? Считается, что политическим идеалом славянофилов было самодержавие [Васильев 2010: 5; Устрялов 1925]. Поэтому вполне естественно искать у Киреевского представления о правителе как Верховном Онтологизаторе. И вот в 
«Записке об отношении русского народа к царской власти» мы как будто бы видим попытку встроить эти представления в этноцивилизационную модель.

Прежде всего, Киреевский пытается по-новому проинтерпретировать идею тождества правителя, государства и страны. Философ заявляет: «Законность, Отечество, Православие суть коренные стихии, из которых слагается понятие русский Царь» [Киреевский 2007: 38]. Здесь царь как бы вбирает в себя означенные стихии.

Однако в пассаже о любви русского народа к государю обнаруживается несколько иная конструкция: «Истинная любовь к Царю соединяется в одно неразделимое чувство с любовью к Отечеству, к законности и к Святой Православной Церкви. $<\ldots>$ Закон - это воля Царя, перед всем народом объявленная; Отечество - это лучшая любовь его сердца; Святая Православная Церковь - это его высшая связь с народом, это самое существенное основание его власти, причина доверенности народной к нему, совокупная совесть его и Отечества, живой узел взаимного сочувствия Царя и народа, основа их общего благоденствия, источник благословения Божьего на него и на Отечество. Но любить Царя русского раздельно от России - значит любить внешнюю силу, случайную власть, а не русского Царя <...>» [ibid. 33].

Здесь перед нами открывается вариант некоего эротического единства. Эрос народа восходит к цельности, включающей монарха, землю-страну, законность и церковь. Так эротический объект видится взгляду, направленному от народа. Но взгляд, устремленный $\kappa$ народу, открывает уже другую картину. Царь становится персонификацией цельности, выступающей как эротический субъект. Его Эрос нацелен на страну-землю, а воля-закон - на народ. Однако связь царя с народом не только волевая, но и со-чувственная, т.е. тоже эротическая. А со страной-землей монарха соединяет также со-весть - общее нравственное со-знание. Возникает триединая сверхцельность: царь - страна-земля - народ. Церковь же превращается в бытийное основание этой сверхцельности, основу ее внутренних связей. Реконструируемая сверхцельность может быть понята как симфоническая личность.

Свои онтологизационные функции монарх выполняет посредством упорядочивания социума. При этом, однако, правитель должен стремиться к полному растворению в упорядочиваемой целостности: «<..> Конечная цель развития законности в России, где самодержавие само собою и заметно исчезнет в твердости общего порядка, - не только не противно воле Самодержца русского, но, без малейшего сомнения, составляет самую главную мысль и постоянную цель всех его трудов и забот о благе и устройстве государственном» [ibid. 55]. На этом пути самодержавие лишается самостоятельной ценности.

Дальше - больше. Монарх в своей онтологизационной функции постепенно подменяется и вытесняется церковью. Царь служит церкви [ibid. 34-35]. Церковь же выступает источником бытия страны-земли, «составляет ее существенную особенность, ее душу и коренное условие ее правильного и благополучного возрастания» [ibid. 40-41].

Когда же речь заходит об исконно русском просвещении, то самодержавие и вовсе оказывается его разрушителем. В «Записке» эта мысль смягчена. Здесь монарх лишь довершает дело, подчиняясь исторической необходимости: «Действие Православной Церкви на древнюю Россию было всеобъемлющее. Вся ее новообразующаяся жизнь была проникнута ею. Но влияния чужих народностей и, может быть, нравственные слабости и человеческие пороки внутри ее изменили еще гораздо прежде Петра правильность этого недостроившегося христианского образования и остановили его на полудороге. Тогда чужеземная образованность сделалась необходимою. Произошел тяжелый переворот Петра» [ibid. 44]. А вот в «Ответе А. С. Хо- 
мякову» Киреевский не стесняется задавать неудобные вопросы: «Как возможен был Петр, разрушитель русского и вводитель немецкого? Если же разрушение началось прежде Петра, то как могло Московское княжество, соединивши Россию, задавить eе?» [Киреевский 1984: 126]. При этом монарх уже не выступает тут персонификацией этноцивилизационной цельности. Напротив, «Петр, как начальник партии в государстве, образует общество в обществе» [ibid.].

В «Записке» настойчиво повторяется мысль о православии как основе истинного просвещения: «Православие не только не противно истинному просвещению, но, напротив, требует его для своего процветания в народе и человеке и само составляет его вернейшую основу и, можно сказать, единственное условие его правильного и нравственно свободного развития. Оно не только не разрушается наукою, но еще более укрепляется ею в умах, само своим вдохновительным действием оживляя правильную деятельность разума» [Киреевский 2007: 46].

Все это свидетельствует о том, что традиционная онтологическая модель у Киреевского не работает. Более того, она ему в действительности и не нужна. Ведь «Записка», в которой он не слишком убедительно пытается приспособить эту модель к своим идеям, вызвана к жизни ситуацией, когда Киреевский и его товарищи по «Московскому сборнику» вынуждены оправдываться перед властями и доказывать: мол, «мы в образе мыслей наших не отделяем Царя от России» [ibid. 31].

Есть, однако, традиция, от которой философ не отказывается. Чтобы понять, о чем идет речь, нужно вернуться к проблеме вербализма Киреевского. Ю. М. Лотман пишет: «Одной из особенностей русской средневековой культуры был особый авторитет Слова. Слово совмещает в себе и разум, и речь, и одно из наименований Сына Божия, и данный им людям закон. < .. > В этом смысле естественно, что когда место религиозного авторитета оказалось вакантным, его заняло искусство Слова. Представление о поэте как о пророке, носителе высших начал, приосененном высшим авторитетом, утверждается в литературе XVIII очень рано» [Лотман 1997: 121]. Впрочем, говорить здесь можно не только о поэте, но и о литераторе вообще.

XIX век подтверждает сакральный статус литератора и литературы. «<...> В 1830 - 1840-е годы фактом сознания все увеличивающейся русской читающей публики делается учительская роль писателя. Наряду с "Мертвыми душами" и "Выбранными местами из переписки с друзьями” Гоголя, философическим циклом Чаадаева, - статьи Хомякова, И. Киреевского, К. Аксакова в большей или меньшей степени несут на себе печать боговдохновенного поучения» [Песков 1992: 107].

И вот в письме Киреевского Кошелеву, датированному 1827 годом, находим следующую декларацию: «Но целую жизнь имея главною целью образовываться, могу ли я не иметь веса в литературе? Я буду иметь его и дам литературе свое направление. $<$...> Кроме того, слушай одно из моих любимых мечтаний: у меня четыре брата, которым природа не отказала в способностях. Все они будут литераторами, и у всех будет отражаться один дух. <.. > У нас все будет общая цель - благо отечества и общее средство - литература. <..> Мы возвратим права истинной религии, изящное согласим с нравственностию, возбудим любовь к правде, глупый либерализм заменим уважением законов и чистоту жизни возвысим над чистотою слога» [Киреевский 1984: 288-289].

Литератор как носитель сакрального слова выступает по отношению к обществу в роли пророка и законодателя. Онтологизация общества понята тут как его упорядочение (космизация), осуществляемое путем утверждения религиозного и гражданского закона. Сам онтологизатор обретает свой статус через причастность просвещению. Здесь перед нами онтологизационная модель, которую можно назвать пророческой. 
Таким образом, очевидными являются следующие моменты. Во-первых, хотя славянофильски-почвенническое Просвещение и декларирует необходимость некоего возвращения к культурным истокам, в нем сразу же проявляется тенденция к уменьшению роли традиционных механизмов онтологизации. Во-вторых, здесь четко прослеживается связь с предшествующими этапами развития Просвещения на русской почве (пророческая модель). И в-третьих, данной ветви Просвещения отнюдь не чуждо новаторство (этноцивилизационная модель). Причем специфика этого сегмента просвещенческого континуума во многом определяется именно новшествами.

\section{СПИСОК ЛИТЕРАТУРЫ}

Антонов, К. М. (2006). Философия И. В. Киреевского: антропологический аспект. Москва: Издательство ПСТГУ.

Баженова, Т. П. (2004). Русское просвещение как проявление европеизации русской культуры. Аналитика культурологии. Электронное научное издание, 1. Отримано з http://www.analiculturolog.ru/journal/archive/item/74-russian-education-as-a-manifestationof-europeanization-russian-culture.html

Баженова, Т. П., \& Семина, В. С. (2008). Сущность европеизации русской культуры. Аналитика культурологии. Электронное научное издание, 1(10). Отримано 3 http://www.analiculturolog.ru/journal/archive/item/548-article_30-2.html

Василий (Саяпин), иеромонах, \& Шарипов, А. М. (2006). Иван Васильевич Киреевский: Возвращение к истокам. Москва: Издательство Главархива Москвы.

Васильев, А. А. (2010). Государственно-правовой идеал славянофилов. Москва: Институт русской цивилизации.

Гальперин, С. (2010, 10 мая). Иван Киреевский и его идея цельного знания. Отримано 3 http://ruskline.ru/analitika/2010/05/10/ivan kireevskij i ego ideya celnogo znaniya

Дорофей, авва. (2010). Преподобного отия нашего аввы Дорофея душеполезные поучения и послания. С присовокуплением вопросов его и ответов на оные Варсануфия Великого и Иоанна Пророка. Москва: Благовест.

Живов, В. М., \& Успенский, Б. А. (1987). Царь и Бог: Семиотические аспекты сакрализации монарха в России. In Б. А. Успенский (Ред.), Языки культур и проблемы переводимости (сс. 47-53). Москва: Наука. Отримано 3 http://krotov.info/history/18/1/uspen_09.htm

Зеньковский, В. В. (1991). История русской философии, в 2 mm. (4 кн.). Ленинград: Эго.

Земницкая, М. А. (2011). Православное Просвещение: синтез государственной и церковной идеологии. In П. С. Кабытов, (Ред.), Платоновские чтения. ХVII Всероссийская конференция молодых историков (Самара, 25-26 ноября 2011 г.) Материалы и доклады (сс. 159-161). Самара: Издательство «Самарский университет».

Ильин, Н. П. (2008). Трагедия русской философии. Москва: Айрис-пресс.

Каменский, 3. А. (2003). Философия славянофилов. Иван Киреевский и Алексей Хомяков. Санкт-Петербург.: Изд.

Каплин, А. Д. (2008). Мировоззрение славянофилов. История и будущее России. Москва: Институт русской цивилизации.

Каплин, А. Д. (2011). Славянофилы, их сподвижники и последователи. Москва: Институт русской цивилизации.

Катасонов, В. Н. (2000). Концепция целостного разума в русской философии и Православие. In В. Л. Шленов, \& Л. Г. Петрушина (Сост.), Рождественские чтения'2000: Христианство и философия. Москва: Московский Патриархат, Отдел религиозного образования и катехизации. Отримано з http://www.katasonov-vn.narod.ru/celr.html 
Киреевский, И. В. (2007). Духовные основы русской жизни. Москва: Институт русской цивилизации.

Киреевский, И. В. (1984). Избранные статьи. Москва: Современник.

Киреевский, И. В. (1911). Полное собрание сочинений в 2-x томах. Москва: Типография Императорского Московского Университета.

Киреевский, И. В. (2002). Разум на пути к истине. Москва: Правило веры.

Котельников, В. А. (1984). Литератор-философ. In И. В. Киреевский, Избранныле статьи (сс. 5-28). Москва: Современник.

Кузнецов, В. Г. (2013). Просвещение и онтология. Просвещения автохтонные: Европа. Sententiae, 28(1), 120-137.

Кузнецов, В. Г. (2014). Просвещение и онтология. Просвещения автохтонные: Китай. Sententiae, 30(1), 129-146.

Лотман, Ю. М. (1997). О русской литературе. Статьи и исследования (1958-1993). СанктПетербург: Искусство.

Лукин, П. В. (2000). Народные представления о государственной власти в России ХVI века. Москва: Наука.

Маслин, М. А. (Ред.). (2007). Русская философия: Энциклопедия. Москва: Алгоритм.

Михайлов, А. Ю. (2013). Ключевые концепты описания православия в модернизирующейся Российской империи: проблема формулирования, аналитический язык. Вестник Удмуртского университета, 3, 105-111.

Морозова, О. М. (2010). Он и она у порога хаоса. Николай II и Александра Федоровна в годы Великой войны. Диалог со временем. Альманах интеллектуальной истории, 31, 154-175.

Морозова, О. М. (2006). Сакральный царь, убивший Николая? In П. Н. Лукичев (Ред.), Лосевские чтения: Труды Международной ежегодной научно-теоретической конференции (май 2006; г. Новочеркасск). Новочеркасск: Набла ЮРГТУ (НПИ). Отримано 3 http://www.relga.ru/Environ/WebObjects/tguwww.woa/wa/Main?textid=2125\&level1=main\&level2=articles

Муза, Д. Е. (2009). Целостный человек как ближайшая цель восточно-христианского культурного проекта. Ученые записки Таврического начионального университета им. В.И. Вернадского. Серия «Философия. Сочиология», 1, 83-93.

Песков, А. М. (1992). Германский комплекс славянофилов. Вопросы философии, 8, 105-120.

Платонов, О. А. (Ред.). (2009). Славянофиль. Историческая энциклопедия. Москва: Институт русской цивилизации.

Пустарнаков, В. Ф. (1999). Еще раз о сущности философии русского Просвещения 1860-х гг. и впервые о его кризисе. История философии, 4, 57-88.

Пустарнаков, В. Ф. (2001). Философия Просвещения в России и во Франции: опыт сравнительного анализа. Москва: ИФ РАН. Отримано 3 http://philosophy2.ru/iphras/library/pustarnikov/prosv.htm

Рожковский, В. Б. (2004). Идея иельного духа у И. В. Киреевского: культурологическая реконструкиия. Ростов-на-Дону: ДГТУ.

Симосато, Т. (1995). Кризис Просвещения в России и аксиология П. Н. Ткачева. Вестник Московского университета. Серия 7. Философия, 1, 18-26.

Судаков, А. К. (2011). «Особенность России»: Иван Киреевский о русской идее и русской беде. Вестник Русской христианской гуманитарной академии, 12(3). 159-173.

Судаков, А. К. (2012). Философия иельной жизни. Миросозериание И. В. Киреевского. Москва: «Канон+», \& РООИ «Реабилитация».

Устрялов, Н. В. (1916). Национальная проблема у первых славянофилов. Русская мысль, Х. Отримано 3 http://lib.ru/POLITOLOG/ustrqlow3.txt

Устрялов, Н. В. (1925). Политическая доктрина славянофильства. Харбин: Типография Китайской Восточной железной дороги. Отримано 3 http://lib.ru/POLITOLOG/ustrqlow.txt

Цапина, О. А. (2004). Православное Просвещение - оксюморон или историческая реальность? In С. Я. Карп, \& С. А. Мезин (Ред.), Европейское Просвещеение и циивилизация России (сс. 301-313). Москва: Наука. 
Чикова, В. А. (2015). Взаимодействие светского и церковного начал в общественной жизни России в середине XVIII века. Научный диалог, 12(48), 400-411.

Hunter, I. (2003). Rival Enlightenments: Civil and Metaphysical Philosophy in Early Modern Germany. Cambridge: Cambridge UP.

Wirtschafter, E. K. (2009). Thoughts on the Enlightenment and Enlightenment in Russia. Modern Russian History \& Historiography, 2(2), 1-26. https://doi.org/10.1163/221023809x00012

Wirtschafter, E. K. (2010). Religion and Enlightenment in Eighteenth-Century Russia: Father Platon at the Court of Catherine II. Slavonic \& East European Review, 88(1/2), 180-203.

Wirtschafter, E. K. (2013). Religion and Enlightenment in Catherinian Russia: The Teachings of Metropolitan Platon. DeKalb: NIU Press.

Получено 29.09.2016

\section{REFERENCES}

Antonov, K. M. (2006). Philosophy by I. V. Kireyevski: anthropological aspect. [In Russian]. Moscow: PSTGU.

Basil (Sayapin), monk, Sharipov, A. M. (2006). Ivan Kireyevsky: Back to basics. [In Russian]. Moscow: Glavarchiv.

Bazhenova, T. P. (2004). Russian Enlightenment as a manifestation of the Europeanization of Russian culture. [In Russian]. Analitika kulturologii, 1. Retrieved from http://www.analiculturolog.ru/journal/archive/item/74-russian-education-as-a-manifestation-ofeuropeanization-russian-culture.html

Bazhenova, T. P., \& Syomina, V. S. (2008). The essence of the Europeanization of Russian culture. [In Russian]. Analitika kulturologii, 1(10). Retrieved from http://www.analiculturolog.ru/journal/ archive/item/548-article_30-2.html

Chikova, V. A. (2015). The interaction of secular and church began in the public life of Russia in the middle of the XVIII century. [In Russian]. Nauchnyj dialog, 12(48), 400-411.

Dorotheus, Abba. (2010). The teachings and epistles of our father Abba Dorotheus. [In Russian]. Moscow: Blagovest.

Halperin, S. (2010, May 10). Ivan Kireyevsky and his idea of integral knowledge. [In Russian]. Retrieved from http://ruskline.ru/analitika/2010/05/10/ivan_kireevskij_i_ego_ideya_celnogo_znaniya

Hunter, I. (2003). Rival Enlightenments: Civil and Metaphysical Philosophy in Early Modern Germany. Cambridge: Cambridge UP.

Ilyin, N. (2008). The tragedy of Russian philosophy. [In Russian]. Moscow: Airis-press.

Kamensky, Z. A. (2003). The philosophy of the Slavophiles. Ivan Kireyevsky and Alexei Khomyakov. [In Russian]. St. Petersburg: RHGI. Retrieved from http://philosophy2.ru/library/kamensky/slavian/ 01.htm

Kaplin, A. D. (2008). World view of the Slavophiles. The history and future of Russia. [In Russian]. Moscow: Institute of Russian civilization.

Kaplin, A. D. (2011). The Slavophiles, their associates and followers. [In Russian]. Moscow: Institute of Russian civilization.

Katasonov, V. N. (2000). The concept of holistic mind in Russian philosophy and Christianity. In V. L. Shlenov, \& L. G. Petrushina (Eds.), Christmas readings'2000: Christianity and philosophy. [In Russian]. Moscow: The Moscow Patriarchate, Department of Religious Education and Catechesis. Retrieved from http://www.katasonov-vn.narod.ru/celr.html

Kireyevsky, I. V. (1911). Complete Works in 2 vols. [In Russian]. Moscow: Printing of the Imperial Moscow University.

Kireyevsky, I. V. (1984). Selected articles. [In Russian]. Moscow: Sovremennik.

Kireyevsky, I. V. (2007). Spiritual Foundations of Russian life. [In Russian]. Moscow: Institute of Russian civilization.

Kireyevsky, I.V. (2002). Mind on the way to the truth. [In Russian]. Moscow: Pravilo very.

Kotel'nikov, V. A. (1984). The writer-philosopher. In I. V. Kireyevsky, Selected articles (pp. 5-28). [In Russian]. Moscow: Sovremennik. 
Kuznetsov, V. G. Enlightenment and Ontology. Autochthonous Enlightenments: China. [In Russian]. Sententiae, 30(1), 129-146.

Kuznetsov, V. G. Enlightenment and Ontology. Autochthonous Enlightenments: Europe. [In Russian]. Sententiae, 28(1), 120-137.

Lotman, J. M. (1997). About Russian literature. Articles and Research (1958-1993). [In Russian]. St. Petersburg: Iskusstvo.

Lukin, P. V. (2000). People's ideas about state power in Russia of the XVII century. [In Russian]. Moscow: Nauka.

Maslin, M. A. (Ed.). (2007). Russian philosophy: Encyclopedia. [In Russian]. Moscow: Algorithm.

Mikhailov, A. J. (2013). Key concepts to describe Orthodoxy in modernizing the Russian Empire: problem formulation, analytical language. [In Russian]. Bulletin of Udmurt University, 3, 105-111.

Morozova, O. M. (2006). The sacred king who killed Nicholas. In P. N. Lukichev, (Ed.), The readings in honor of A. F. Losev. [In Russian]. Novocherkassk: Nabla YuRGTU (NPI). Retrieved from http://www.relga.ru/Environ/WebObjects/tguwww.woa/wa/Main?textid=2125\&level1=main\&level2=articles

Morozova, O. M. (2010). He and she are at the threshold of chaos. Nicholas II and Alexandra during the Great War. Dialogue with time. [In Russian]. Almanac of intellectual history, 31, 154-175.

Musa, D. E. (2009). Holistic man like immediate goal of Eastern Christian cultural project. [In Russian]. Scientific notes of Taurida National V. I. Vernadsky University. Series «Philosophy. Sociology», 1, 83-93.

Peskov, A. M. (1992). German complex of the Slavophiles. [In Russian]. Voprosy filosofii, 8, 105-120.

Platonov, O. A. (Ed.). (2009). The Slavophiles. Historical Encyclopedia. [In Russian]. Moscow: Institute of Russian civilization.

Pustarnakov, V. F. (1999). Once again about the nature of Russian philosophy of the Enlightenment of the 1860s. and for the first time of his crisis. [In Russian]. Istoriya filosofii, 4, 57-88.

Pustarnakov, V. F. (2001). Enlightenment philosophy in Russia and in France: experience of comparative analysis. [In Russian]. Moscow: IF RAN. Retrieved from http://philosophy2.ru/iphras/library/pustarnikov/prosv.htm

Rozhkovsky, VB (2004). The idea of holistic spirit in I. V. Kireyevski: culturological reconstruction. [In Russian]. Rostov-on-Don: DGTU.

Shimosato, T. (1995). Crisis of the Enlightenment in Russia and axiology by P. N. Tkachev. [In Russian]. Bulletin of Moscow University. Series 7. Philosophy, 1, 18-26.

Sudakov, A. K. (2011). «The peculiarity of Russia»: Ivan Kireyevsky about the Russian idea and the Russian disaster. [In Russian]. Bulletin of RHGA, 12(3). 159-173.

Sudakov, A. K. (2012). Philosophy of holistic life. World view by I. V. Kireyevsky. [In Russian]. Moscow: «Kanon+» ROOI «Reabilitaziya».

Tsapina, O. A. (2004). Orthodox Enlightenment - oxymoron or historical reality? In S. Ya. Carp, \& S. A. Mezin (Eds.), The European Enlightenment and Russian civilization (pp. 301-313). [In Russian]. Moscow: Nauka.

Ustrialov, N. (1916). National problem at the first Slavophiles. [In Russian]. Russkaya mysl, X. Retrieved from http://lib.ru/POLITOLOG/ustrqlow3.txt

Ustrialov, N. (1925). The political doctrine of Slavophilism. [In Russian]. Harbin: Printing the Chinese Eastern Railway. Retrieved from http://lib.ru/POLITOLOG/ustrqlow.txt

Vasiliev, A. A. (2010). Public-legal ideal of the Slavophiles. [In Russian]. Moscow: Institute of Russian civilization.

Wirtschafter, E. K. (2009). Thoughts on the Enlightenment and Enlightenment in Russia. Modern Russian History \& Historiography, 2(2), 1-26. https://doi.org/10.1163/221023809x00012

Wirtschafter, E. K. (2010). Religion and Enlightenment in Eighteenth-Century Russia: Father Platon at the Court of Catherine II. Slavonic \& East European Review, 88(1/2), 180-203.

Wirtschafter, E. K. (2013). Religion and Enlightenment in Catherinian Russia: The Teachings of Metropolitan Platon. DeKalb: Northern Illinois UP.

Zemnitskaya, M. A. (2011). Orthodox Enlightenment: synthesis of church and state ideology. In P. S. Kabytov (Ed.), Platonic readings (pp. 159-161). [In Russian]. Samara: Samara University. 
Zhivov, V. M., \& Uspensky, B. A. (1987). Tsar and God: Semiotic aspects of the sacralization of the monarch in Russia. In B. A. Uspensky (Ed.), Languages and Cultures of translatability problems (pp. 47-53). [In Russian]. Moscow: Nauka. Retrieved from http://krotov.info/history/18/1/ uspen_09.htm

Zienkowski, V. V. (1991). The history of Russian philosophy. In 2 vol. [In Russian]. Leningrad: Ego.

Received 29.09.2016

\section{Vsevolod Kuznetsov}

\section{Enlightenment and ontology. Russian Preclassic Enlightenment: Kireyevsky}

This work continues a series of articles The Enlightenment and ontology. It investigates the ontological component of the Russian Preclassic Enlightenment. The author claims that the Russian Enlightenment arises in the 30s-40s of XIX century. As the founders of the Russian Preclassic Enlightenment he considers Kireyevsky, Chaadayev and Herzen. This article considers the philosophy of Kireyevsky.

Based on the concept of the nature and features of the Enlightenment, developed in the preceding articles, the author argues that Kireyevsky is a figure of the Enlightenment. The basic concept in the philosophy of Kireyevsky is the concept of education. It is a process of transformation of reality under the influence of education and the result of this process - a certain state of spirituality. The Russian Orthodox education formed the basis of Russian civilization and the very nature of the Russian people. The influence of Western education damaged the foundations of civilization and the nature of the people. To correct damage is possible by means of a new philosophy which should be based on the synthesis of Christian Orthodox and Western education. The aim of this project is to implement the utopia of holistic man. Kireyevsky also emphasizes the inextricable and essential link between the Russian Education and literature. This allows to consider Kireyevsky as the representative of the Enlightenment.

The author also shows that Kireyevsky constructs two ontological models. The first model could be called ethnic and civilizational. Civilization is a phenomenon, able to change its own ontological status. The second model can be called prophetic. As a carrier of the sacred word, a writer appears as a prophet and lawgiver. His work provides the highest ontological status for society. The first model is new. The second model descends from the previous stages of development of the Russian Enlightenment. At the same time Kireyevsky tries to overshadow the traditional ontological model where the main role is played by the sacred tsar, even though the traditional model was basic then in Russia.

Vsevolod Kuznetsov, Senior lecturer of Philosophy Department at Vinnytsia National Technical University.

Всеволод Кузнецов, старший викладач кафедри філософії Вінницького національного технічного університету.

Всеволод Кузнецов, старший преподаватель кафедры философии Винницкого национального технического университета.

e-mail:okkuznetsov@rambler.ru 